\title{
Technological research methodology to manage organizational change
}

\author{
Hilda A. Del Carpio Ramos \\ Unidad de Investigación FACEAC \\ Universidad Nacional Pedro Ruiz \\ Gallo \\ Lambayeque, Perú \\ angelicadcr@hotmail.com
}

\author{
Pedro A. Del Carpio Ramos \\ Unidad de Investigación FIZ \\ Universidad Nacional Pedro Ruiz \\ Gallo \\ Lambayeque, Perú \\ delcarpiofiz@hotmail.com
}

\author{
Francisco José García- \\ Peñalvo \\ IUCE, Universidad de Salamanca \\ Salamanca, España \\ fgarcia@usal.es
}

\begin{abstract}
Change is a process that is part of the nature of people; however, within organizations, it should be seen as an invention that will generate benefits in the markets. The main objective of this work is to design a technological methodology to manage change from seven administrative models. For this, a bibliographic review was carried out; the method applied was analysis-synthesis; the example technique was used to comment; the support instruments were a standard data collection form and a comparative table to analyze this data vertically and horizontally. The methodology was validated in the research units of a local university. The main results were 1) The change of management within organizations is an invention; 2) administrative models of change are used to manage it; 3) but, to be successful in managing change, the methodology of technological research is required in addition to the
\end{abstract} administrative process.

\section{KEYWORDS}

Change, Change management, Technological research methodology, Change management models.

\section{Introduction}

It is a known and accepted fact that the human being is an animal of habits, since it adapts easily to an environment, so when it comes to changing those customs an atmosphere of discomfort is generated because it is thought that they would never change; as in the classic example of mice that assume that their cheese will always be available to them in a certain place and never anticipate that such a situation could change [1].

In organizations, the purpose of change management should no longer be the resistance offered by staff, but the changes that must be made in the organization. The concern about the change went from being attitudinal to technical.

The technique indicates what and how to make the change and try it; It facilitates and leads to innovation through the transformation of individual knowledge into organizational $[2,3,4]$.

Considering change as a technical problem allows validating a qualitative and quantitative intervention plan or program, ensuring the success of management and investment [5]. It is not just the effect of changing [6] or changing the state [7], it is much more.

A technical problem is, for example, a new product, a new working method and the way in which it is managed must involve a technological means.

However, change management models based on aspects of behavior and the administrative process that has been generated in the last century, are used until today [8] because they have no technical means to adapt to the current reality.

It is necessary to complete these models with a methodology that originates in the same administrative theories that support them and in the method of technological research.

The methodology will allow focusing on the technical problem instead of the attitude problem and it will be possible to analyze, create, test, verify, apply, disseminate and generalize a new work method or process. 
In this way, technical advantages, higher levels of productivity and competitiveness, more benefits for the market and greater economic income for the organization will be generated.

In this document, seven administrative models are presented that offer representations and metaphors to manage change; but that they do not offer the form of how to administer it, existing in them a methodological void, and for the organization, a high risk of not being able to validate or test their change plans.

Therefore, the general objective of this work was to design, based on the seven models, a methodology of technological research to manage change, without fear and with greater probability of success.

Below is the theoretical basis that supports the design of the proposed methodology.

\subsection{Change}

Change comes from the Latin cambium which means the effect of changing [6].

To change is to move from one system to another, in a way of doing things to a different one [7], or to move from one equilibrium point to another [8].

Change is considered a process in transition; therefore, it implies learning to accept and implement it with what is expected to reduce the social conflicts that it originates [9].

The main conflict that the change originates is the resistance when people refuse to do something different either by habit or by fear.

At the business level, the problem arises because of two circumstances; when it is underestimated how difficult it is for people to make the change; or when the ability of managers to induce change is overestimated [10].

For Kotter cited by McGrath \& Bates [8], change is a permanent process of innovation of ideas and projects to solve the present and future needs of companies.

Change is also considered important to maintain high productivity and competitiveness [6] butas it almost always implies discomfort, theories have been generated to guide it, which are known as, change management models.

For this work, the change within an organization is an invention, configured as a new process or work method to be implemented in a company to obtain greater benefits for the market and the organization [5]. Therefore, just as it is important to manage it, a technological research methodology is also urgently needed to ensure a calm and the proposed success.

\subsection{Change management}

Change management is an orderly activity and requires a planned and committed work of all personnel because resistance to change is frequent; it requires clear commercial policies and sufficient resources to implement it [11].

Change management is inevitable due to technological innovations that occur inside and outside the company; to implement it, people, structures, systems, and cultures must be considered; and implies a professional process to carry it out [12].
Change management is also, considered as a forced, educational or logical strategy, which is necessary to face the resistance to change [13].

Other important strategies are related to the attitude of the staff, for which mechanisms of cooperation, communication, training, participation, support, commitment, negotiation, agreement, manipulation, and coercion are proposed [14].

Change management should consider change as an invention, and use methods, processes and techniques to experiment, apply and evaluate; for example, the baseline for formulating the administrative problem and the technical problem, the change plan as a hypothesis, the evaluation during and after the intervention as a method to determine the success of the change [5], and the system of indicators as an instrument for results presentation [15].

Despite the abundant bibliography, there is no methodology to guide change management.

\subsection{Technological investigation methodology}

Changing the reality of organizations through administrative theories is not enough. It must be complemented with other means, such as the methodology of technological research.

The purpose of technological research is the invention of artifacts and processes. Its field of action is change and the plans that are generated to make the change are considered innovations. Therefore, each process of change requires technological methodologies to manage it, such as new ways of working [16].

It is different from the scientific methodology whose purpose is to analyze the reality of the study to predict the causes and effects of a problem; it is subject to external validity through quantitative techniques and internal validity through qualitative techniques [17].

Instead, a technological methodology is used when the solution is already known. The objective is to apply the solution to transform reality through new intervention processes (change plan or program) [16]. According to García, cited by De La Cruz [18], this methodology includes observation, problem formulation, documentation, creations, intervention program, effectiveness evaluation, communication, implementation, monitoring, and evaluation.

As change is a process to implement a new way of working with the purpose of obtaining benefits inside and outside the company and, as technological research is the invention of artifacts or processes to obtain a benefit, change within the organization is an invention [5]

Consequently, to manage change within organizations, be it in the forms of management, in the working methods, in the product or in the markets, a technological research methodology is needed that should be enriched with the management models. 


\section{Management models}

\subsection{Thaw-Change-Refreeze model}

Kurt Tsadet Lewin (1890-1940), became one of the main representatives of the Gestalt school of Psychology [19]; designed the Defrost-Change-Freeze model [20]. Lewin generated the theory of the field, indicates that the behavior of individuals is due to the interaction of the perceptions of this with their environment [21].

He considers that in each system there are driving and restrictive forces that compete with each other. The driving forces facilitate change while the restrictive forces resist it. For this reason, change refers to the modification of forces within a system. It is about moving from one point of equilibrium of forces to another; and that, since the restrictive forces are predominant, it presents the "Thawing-Change-Refreeze" model [8].

Thawing is the stage that diagnoses the forces that exist in a system; plan change to minimize restrictive forces and increase driving forces; describe the current situation; identify the need for change; formulate the changes; list the factors that cause the driving forces; lists the factors that promote restrictive forces; analyze the factors; identify the optimization potential; and design the change strategy.

Change is the stage of implementation of the change plan and involves training activities of the strategy and implement it until a new balance of forces or state or situation is achieved.

Freezing again is the consolidation and sustainability stage of the change implementation. Present motivational activities. It implies regulating the new state, spreading it and generalizing it.

The model focuses on managing the resistance to change of employees rather than the company's change plans. In addition, no literature has been found that demonstrates that its method has been experimentally tested or that it has a technological tool to implement it.

\subsection{P-D-V-A model}

Walter Andrew Shewhart (1891-1967) is known as the Father of Statistical Quality Control. He designed the PDVA model to make changes within processes or systems through four stages: planning, doing, verifying and acting [8]. This process is also known as the continuous improvement cycle [22].

In the Plan stage, the normal causes and the special causes of the problems are identified; improvement needs and solution alternatives are obtained; each alternative is subject to experimentation and the change plan is drawn up.

In the Do stage, the change plan is implemented. In the Verify stage, the impact of the change made is evaluated. In the Act stage, the change is consolidated.

This model is interesting because by experimenting with the exchange alternatives, the success of the company is guaranteed; however, the tools that allow its application have not been found.

\subsection{Change cycle}

Elisabeth Kübler-Ross (1926 - 2004), designed the "Cycle of Change" model from her work with patients with terminal diseases [23]. Explain that changing habits, systems or roles is a traumatic event until it is accepted [8]; what she calls, going from neophobia (opposition to change) to neophilia (acceptance to change) [24].

The model includes five stages: denial, anger, negotiation, depression and acceptance, and aims to train and prepare the organization's staff to accept the change [23].

The application of the Change Cycle is done through the following steps: Discuss with the employees the change you want to propose; communicate and train the different ways of making the change and designate the drivers of change.

The model focuses on offering strategies to reduce resistance to change rather than changes in the organization. No tools were found to implement the model.

\subsection{Dark side theory}

Gerard Egan was born in 1930; He designed the "Dark Side Theory" to make effective changes within a company, taking into account the various stakeholders involved in it, as partners and allies, opponents, adversaries and spectators [8].

Egan does not directly intervene in the management of the change but indicates that before starting a change, the actors of the company must be identified and grouped according to their interest in the change. In other words, it focuses on preparing the ground for change.

The model does not have an application tool.

\subsection{Masters of Change}

Rosabeth Moss Kanter (1943) is an advisor to large corporations and governments around the world [25]. She argues that managers must gather seven attitudes based on trust to be considered "masters of change." Attitudes are: tune into the environment, use kaleidoscopic thinking, communicate a clear vision, establish coalitions, work with teams, insist and persevere, make everyone a hero [8].

Through the first two attitudes, it is possible to examine the opportunities and threats facing the company and prepare a change plan. With the following three stages, it is possible to motivate and inspire others while taking responsibility for participating in the change. With the last two attitudes, continuity of change is guaranteed.

The model focuses on reducing resistance to change and does not have an application tool.

\subsection{Drivers of Change}

Warner Burke and George Litwin consider that companies present transformational changes or transactional changes [26], for this reason, they propose a causal model that has 4 levels and 12 dimensions that must be taken into account to plan and implement a successful change in an organization [8].

On the first level, transformational change is made that occurs in response to the external environment. On the second level, change occurs in strategic management. In the third, the change is manifested in the management of operations that affects transformational and transactional factors such as motivation that 
in turn affect performance; and on the fourth level, the change occurs in human resources management where performance affects the external environment.

The model considers resistance to change and the company's change plans but does not have an application tool.

\subsection{Change in Eight steps}

John Paul Kotter was born in San Diego, California, the United States, is an expert in business philosophy and his work focuses on change management from the analysis of the future [27]. It proposes three stages in eight steps to analyze, implement and consolidate the change [28].

In the first stage, "Remove Status Quo" considers four steps: create a sense of urgency; form a coalition; create a vision for change and communicate the vision. In the second stage, the "Introduction of new practices" considers three steps: remove obstacles, ensure short-term victories, build on change. In the third stage "Consolidate" considers one step: Anchor the change in the organizational culture.

The model focuses on changing the organization but shows no application tool.

\section{Method}

The work was developed under a qualitative design based on the literature review of seven change management models; the analysis-synthesis method was applied to decompose the study units into parts [29] and then it was systematized in four stages of the administrative process. The technique used was the Example to comment on each model in different bibliographic sources. The instruments used were a standard data sheet to collect data that was systematized, and a comparative table to analyze these data vertically and horizontally. The methodology obtained was validated through a pilot test in the research units of a local university.

\section{Results and Discussion}

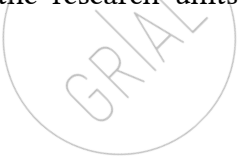

\subsection{Methodology design}

Below is the design process of the technological research methodology to manage organizational change.

All the analyzed models start their design from the diagnosis. In a systematized form, they show the stages of diagnosis, preparation, change, and evaluation. This corresponds to a planned and committed work of all the personnel mentioned by Alonso [11]. This implies the use of the administrative process; that is, the planning to diagnose, the organization to prepare, the execution and direction to change, and control to evaluate (Table 1).
Table 1. Stages of change management according to administrative process

\begin{tabular}{c|c} 
Administrative process & $\begin{array}{c}\text { Stages According to } \\
\text { Models }\end{array}$ \\
\hline Planning & Diagnosis \\
Organization & Preparation \\
Execution and direction & Change \\
Control & Evaluation
\end{tabular}

The stage of Diagnosis to determine the need for change, is represented by the following steps: "thawing" of Lewin [20], "planning" of Shewhart [22], "negotiation and anger" of Ross [23], "tuning in with the environment" of Kanter cited by McGrath \& Bates [8], the "environment" of Burke and Litwin [26],"eliminate the status quo" of Kotter [28] and where identify the actors "allies, comrades and spectators" of Egan cited by McGrath \& Bates [8] (Table 2).

Table 2. Diagnostic steps according to change management models

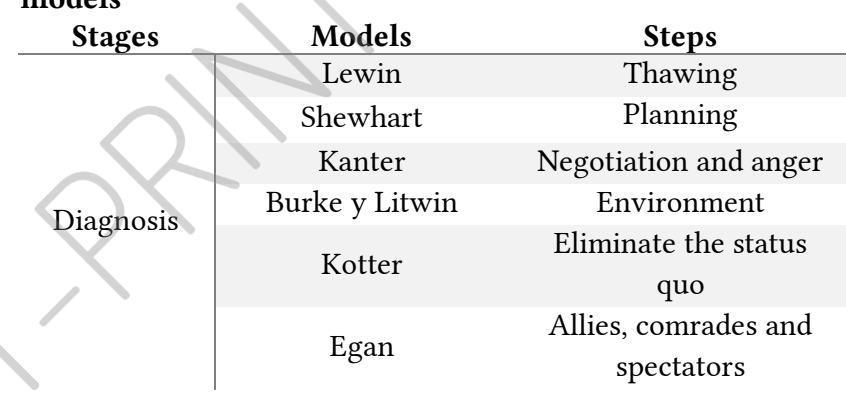

The Preparation stage to analyze and select the solution alternative and to elaborate the change plan, is represented by the following steps: "thawing" of Lewin [20], "doing and verifying" of Shewhart [22], "negotiation and depression" of Ross [23], "kaleidoscope thinking" of Kanter cited by McGrath \& Bates [8], "strategic management" of Burke and Litwin [26], "eliminate the status quo" of Kotter [28] and where identify the actors "bombs, opponents and adversaries" of Egan cited by McGrath \& Bates [8] (Table 3).

Table 3. Preparation steps according to change management models

\begin{tabular}{|c|c|c|}
\hline Stages & Models & Steps \\
\hline \multirow{6}{*}{ Preparation } & Lewin & Thawing \\
\hline & Shewhart & Doing and verifying \\
\hline & Kanter & $\begin{array}{l}\text { Negotiation and } \\
\text { depression }\end{array}$ \\
\hline & Burke y Litwin & Kaleidoscope thinking \\
\hline & Kotter & $\begin{array}{l}\text { Eliminate the status } \\
\text { quo }\end{array}$ \\
\hline & Egan & $\begin{array}{c}\text { Bombs, opponents and } \\
\text { adversaries }\end{array}$ \\
\hline
\end{tabular}

The Change stage to implement the change plan is represented by the following steps: "change" of Lewin [20], "act" of Shewhart [22], "acceptance" of Ross [23], "communicate the vision, establish coalitions, form teams" of Kanter cited by McGrath \& Bates [8], "operations management and human resources administration" of 
Burke and Litwin [26], "new practices" of Kotter [28] and where identify the actors "partners, without voice and partners" of Egan cited by McGrath \& Bates [8] (Table 4).

Table 4. Change steps according to change management models

\begin{tabular}{|c|c|c|}
\hline Stages & Models & Steps \\
\hline \multirow{7}{*}{ Change } & Lewin & Change \\
\hline & Shewhart & Act \\
\hline & Ross & Acceptance \\
\hline & Kanter & $\begin{array}{l}\text { Communicate the } \\
\text { vision, establish } \\
\text { coalitions, form teams }\end{array}$ \\
\hline & Burke y Litwin & $\begin{array}{c}\text { Operations } \\
\text { management and } \\
\text { human resources } \\
\text { administration }\end{array}$ \\
\hline & Kotter & New practices \\
\hline & Egan & $\begin{array}{l}\text { Partners, without voice } \\
\text { and partners }\end{array}$ \\
\hline
\end{tabular}

The last stage Evaluation is only found in some models: in the steps "re-freeze" of Lewin [20], "insist and heroes" of Kanter cited by McGrath \& Bates [8], "administration of operations and administration of human resources" of Burke and Litwin [26], and "consolidate" of Kotter [28] (Table 5).

It is necessary to make a correspondence of the systematized stages of change management models (Diagnosis, preparation, change and evaluation) with the steps of the methodology of technological research (Observation, Formulation of the problem, Documentation, Creations, Intervention program, Assessment of effectiveness, Communication, Implementation, Monitoring and Evaluation) exposed by García, cited by De La Cruz [18].

Table 5. Evaluation steps according to change management models

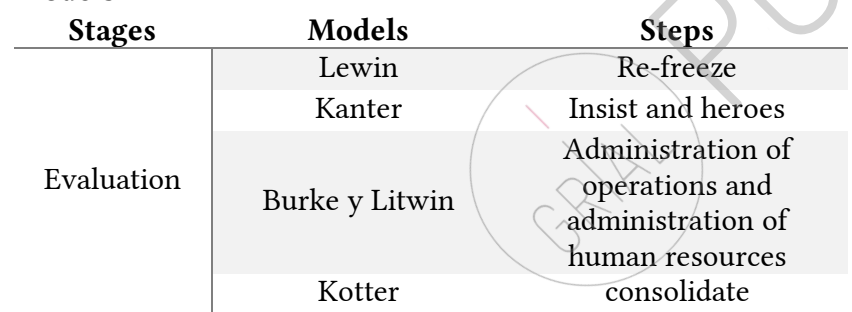

In this aspect, to the Diagnostic stage corresponds the steps "observation, Formulation of the problem and documentation" of the methodology; to the stage Preparation corresponds the steps "creations (invention), program of intervention, effectiveness, and communication"; to the stage Change corresponds the steps "implementation"; and to the Evaluation stage, corresponds the steps "monitoring and evaluation" of the methodology. (Table 6).
Table 6. Correspondence between the stages of change management models with the steps of the technology research methodology

\section{Stages According to change management \\ Technological Research Methodology} Models

Diagnosis
Preparation
Change
Evaluation

Observation

Problem formulation Documentation Creations (invent)

Program of intervention Effective

Communication Implementation Tracing Evaluation

To this correspondence, it is proposed to incorporate, processes, techniques, tools.

The processes are Description (baseline), background, state of the technique, hypothesis, planning, tests, change team, implantation of change, Measurement and Assessment.

The techniques are Description of the reality (qualitative and quantitative), social or economic or environmental or administrative problem, technical problem, change plan, programming, pilots, dissemination and motivation, reports of partial and final execution, evaluation during and after.

The tools are Data record sheet, Indicators system, comparative chart, problems and alternatives diagram, prototype X Proposal, Gantt chart, SPSS statistical system / Excel, banner, electronic panels, brochure, workshop, management information systems, indicators system.

Table 7 shows the consistency of the methodology of the technological research with the processes, techniques and tools, proposed. 
Table 7. Consistency chart: Technological research methodology to manage organizational change

Technological
Research

Methodology

\begin{tabular}{|c|c|c|c|}
\hline A. Observation & $\begin{array}{l}\text { Description } \\
\text { (Baseline } \\
\text { indicator) }\end{array}$ & $\begin{array}{c}\text { Description of } \\
\text { the reality } \\
\text { (Qualitative, } \\
\text { quantitative) }\end{array}$ & $\begin{array}{l}\text { Data record } \\
\text { sheet. } \\
\text { Indicators } \\
\text { system }\end{array}$ \\
\hline $\begin{array}{l}\text { B. Problem } \\
\text { formulation }\end{array}$ & Background & $\begin{array}{c}\text { Social, } \\
\text { economic, } \\
\text { environmental, } \\
\text { Administrative } \\
\text { problem }\end{array}$ & $\begin{array}{c}\text { Comparative } \\
\text { table }\end{array}$ \\
\hline $\begin{array}{l}\text { C. } \\
\text { Documentation }\end{array}$ & $\begin{array}{l}\text { State of the } \\
\text { technique }\end{array}$ & $\begin{array}{l}\text { Technical } \\
\text { problem } \\
\text { Objectives }\end{array}$ & $\begin{array}{l}\text { Interview } \\
\text { Problems and } \\
\text { alternatives } \\
\text { diagram }\end{array}$ \\
\hline $\begin{array}{l}\text { D. Creations } \\
\text { (invent) }\end{array}$ & Hypothesis & $\begin{array}{c}\text { Change plan } \\
\text { design }\end{array}$ & $\begin{array}{l}\text { Prototype / } \\
\text { Proposal }\end{array}$ \\
\hline $\begin{array}{l}\text { E: Intervention } \\
\text { program }\end{array}$ & Planning & Programming & Gantt chart \\
\hline F. Effective & Tests & Pilots & $\begin{array}{c}\text { SPSS } \\
\text { statistical } \\
\text { system / } \\
\text { Excel }\end{array}$ \\
\hline $\begin{array}{l}\text { G. } \\
\text { Communication }\end{array}$ & $\begin{array}{l}\text { Change } \\
\text { equipment }\end{array}$ & $\begin{array}{l}\text { Dissemination, } \\
\text { motivation, } \\
\text { training }\end{array}$ & $\begin{array}{l}\text { Banner / } \\
\text { Electronic } \\
\text { panel, } \\
\text { Brochure, } \\
\text { workshop }\end{array}$ \\
\hline $\begin{array}{l}\mathrm{H} . \\
\text { Implementation }\end{array}$ & $\begin{array}{l}\text { Implantation } \\
\text { of the change }\end{array}$ & $\begin{array}{l}\text { Execution and } \\
\text { final reports }\end{array}$ & $\begin{array}{c}\text { Management } \\
\text { information } \\
\text { systems }\end{array}$ \\
\hline $\begin{array}{l}\text { I. Tracing and } \\
\text { J. Evaluation }\end{array}$ & $\begin{array}{c}\text { Measurement. } \\
\text { Assessment }\end{array}$ & $\begin{array}{c}\text { Indicators } \\
\text { during and } \\
\text { after }\end{array}$ & \\
\hline
\end{tabular}

In this way, it has a methodology of technological research to manage change in organizations, reducing the chances of failure to implement innovation within companies.

The methodology is composed of four stages, ten steps, nine processes, eleven techniques and nine tools

For the massive use of this technology is required, it is necessary to continue with the research to operate it through a computerized mechanism.

\subsection{Results of the pilot test}

The methodology of technological research to manage organizational change was validated by means of a pilot test in ten of the fourteen Research Units of a local university.

The test was conducted from January to June of the year 2019 and had the support of the students of the Professional Statistics and Administration Schools of that university.

The results of the pilot test are presented below:

I- Diagnosis:

A. Observation

In the first month, the Data Record Tab was applied. The qualitative description of the initial reality was made (Baseline). It was found that the Research Units of the local university have only support bodies. Not having support organs means that they cannot fulfill all the functions required by the Organization and Functions Regulation (ROF, acronym in Spanish); and therefore, their products are insufficient (Table 8).

Table 8. Data Record tab of the Research Unit

\begin{tabular}{|c|c|c|c|c|c|}
\hline \multicolumn{6}{|c|}{ Description of reality as of January 2019} \\
\hline Company & \multicolumn{5}{|l|}{ Facultad X } \\
\hline $\begin{array}{l}\text { Business } \\
\text { name }\end{array}$ & \multicolumn{5}{|c|}{ Research unit } \\
\hline $\begin{array}{l}\text { Company } \\
\text { turn }\end{array}$ & \multicolumn{5}{|l|}{ Research } \\
\hline Condition & \multicolumn{5}{|l|}{ Working } \\
\hline Address & \multicolumn{5}{|c|}{ University campus } \\
\hline Head & \multicolumn{5}{|c|}{ Director of the Research Unit } \\
\hline Market & \multicolumn{5}{|c|}{ University community of the Faculty $\mathrm{X}$} \\
\hline \multirow{8}{*}{$\begin{array}{c}\text { ROF } \\
\text { function }\end{array}$} & \multicolumn{5}{|c|}{ Propose lines of research of the Faculty } \\
\hline & \multicolumn{5}{|c|}{ Ensure formative research } \\
\hline & \multicolumn{5}{|c|}{ Coordinate the development of research projects } \\
\hline & \multicolumn{5}{|c|}{ Coordinate interdisciplinary research between Faculties } \\
\hline & \multicolumn{5}{|c|}{ Propose to the members of the Scientific Committee } \\
\hline & \multicolumn{5}{|c|}{ Appoint thesis advisors and jurors } \\
\hline & \multicolumn{5}{|c|}{$\begin{array}{l}\text { Systematize and publish the approved research projects and } \\
\text { supported theses }\end{array}$} \\
\hline & \multicolumn{5}{|c|}{ Promote the edition of the scientific journal, virtual or printed } \\
\hline & \multicolumn{3}{|c|}{0} & \multicolumn{2}{|c|}{0} \\
\hline & \multicolumn{3}{|c|}{ Direction } & \multicolumn{2}{|c|}{$\begin{array}{l}\text { Scientific Committee } \\
\text { (Thesis Jury) }\end{array}$} \\
\hline Prod & $\begin{array}{l}\text { Project } \\
\text { Resolution } \\
\text { (professor) }\end{array}$ & $\begin{array}{l}\text { Final } \\
\text { repor } \\
\mathrm{t}\end{array}$ & $\begin{array}{l}\text { Conference } \\
\text { report }\end{array}$ & $\begin{array}{l}\text { Thesis } \\
\text { project } \\
\text { resolution }\end{array}$ & $\begin{array}{c}\text { Thesis } \\
\text { act }\end{array}$ \\
\hline
\end{tabular}

In the same month, the quantitative description of the initial reality (baseline) was made. The indicators were designed according to the products that the Research Units should obtain. Thus, 16 Indicators correspond to Projects and Thesis; to the Projects and Final Report of the research work of the professors, 12; to the Conference and management reports, 6; and for Articles, Magazines and Seedbeds, they have 6 indicators.

The data was processed in Excel based Indicator System. The system presents a percentage scale to measure the level of compliance of 36 indicators. The levels of compliance are three and determine the level of problem presented by the Units, in terms of management (Table 9).

Table 9. Compliance level scale

\begin{tabular}{|c|c|c|}
\hline Scale & Compliance level & Problem level \\
\hline$<=25 \%$ & Very little & Deficiency \\
\hline$>25-<51 \%$ & Little & Weakness \\
\hline$>50-<76 \%$ & Regular & Limitation \\
\hline
\end{tabular}

The results of the analysis at the beginning of the intervention program (Pilot test) were: In the four products (Thesis Management, Management of the research work of the professors, Management of Research Days and Management of Scientific Articles and others) of the Units Research from the local University, the level of compliance was poor and, therefore, there were deficiencies. (Table 10). 
Table 10. Level of compliance with the management of research work of professors

\begin{tabular}{|l|c|c|c|}
\hline \multirow{2}{*}{ Product } & \multicolumn{2}{|c|}{ Índex } & \multirow{2}{*}{ Total } \\
\cline { 2 - 4 } 1 Thesis management & Yes & No & $100 \%$ \\
\hline 2 Research work management & $25 \%$ & $75 \%$ & $100 \%$ \\
\hline 3 Research days management & $16 \%$ & $83 \%$ & $100 \%$ \\
\hline $\begin{array}{l}\text { 4 Management of Articles, Magazines } \\
\text { and Seedbeds of research }\end{array}$ & $16 \%$ & $83 \%$ & $100 \%$ \\
\hline $\begin{array}{c}\text {-Compliance level } \\
\text {-Problem level }\end{array}$ & \multicolumn{3}{|c|}{$\begin{array}{c}\text { Very little } \\
\text { Deficiencies }\end{array}$} \\
\hline
\end{tabular}

\section{B. Problem formulation}

In the second month, the national background review [30; 31; 32] and international $[33 ; 34)$ to determine whether the initial problem regarding the level of compliance presented by the Research Units of the local University is social, economic, environmental or administrative.

Functional criteria analysis included: Existence of lines and research plan, scientific committee, Thesis concluded, research professors, final research reports, training research media, financing, grants, and quality system.

The analysis of the organizational criteria included: Presence of leadership, areas for the scientific committee, ethics committee, research promotion, thesis management, teaching research management, research days, intellectual property, innovation and transfer, quality assessment, and infrastructure and equipment.

Because the deficiencies focused on functional and organizational aspects, the problem was considered administrative.

This administrative problem (problem A) was formulated as follows: There are management deficiencies in the Research Units of the local University.

\section{Documentation}

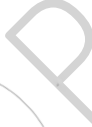

In addition, in the same month, the interview was applied to the heads of the Research Units following the Indicator System. It was determined that the factors that originate in Problem A are related to human resources, procedures, and infrastructure.

University Law [35] and other theories [31; 36; 37] were consulted to analyze the existing organizational designs and functions. By not finding models in a specific model, it was determined that the origin of problem $\mathrm{A}$ is a technical problem (problem T).

This problem $\mathrm{T}$ was formulated as follows: Lack of a specific model of organization and functions of university research at the level of the Research Unit of the local University.

To manage the change and solve the technical problem, three alternatives were formulated:

1) Prepare an Organization Manual of the Research Unit according to the Law 30220 [35]

2) Develop a Model of Organization and Functions of the Research Unit according to the Model RMM [36] and the Law 30220 [35]

3) Prepare a Manual of Functions of the Research Unit of the local University according to the Organizational Structure Model [37] and the Law 30220 [35].

\section{II- Preparation}

D. Creation (Invent)

In the third month, the invention was designed. This was represented by the selection of the second alternative that was assumed as Hypothesis: "Develop a model of organization and functions of the research units in accordance with the RMM Model [36] and Law 30220 [35] to improve their level of compliance."

From this hypothesis, the Change Plan was designed, which consisted of the set of strategic actions that as part of the Improvement Proposal is part of the Rapid Intervention Program from April to June.

E. Intervention program

In the same month, the intervention program that included the planning of the pilot activities to be executed in three months was prepared. The Gantt Diagram was used.

The activities were programmed according to the factors: Human Resources, Procedures and Infrastructure.

\section{F. Effective}

In the same month, preparations were made to validate the intervention program through a pilot test. In this case, it was applied in three months and to ten Research Units.

\section{G. Communication}

In the same month, the Team that implemented the change was formed. It was carried out, dissemination, motivation and training, before implementing the program. It became known with banner, posters and brochures. Orientation workshops were held.

\section{III- Change}

H. Change

From the fourth to the sixth month, the intervention program was implemented to change the problem in solution. Only the final report was issued due to the short term in which it was implemented.

IV- Evaluation

I. Measurement

The results of the analysis at the end of the intervention program (pilot test) were: In the first three products of the Research Units, the level of compliance was regular, which meant that the problem ceased to be deficient and became limited management.

In the case of article management, the problem remained poorly managed, probably due to the short duration of the pilot test (Table 11).

Table 11. Thesis management compliance level

\begin{tabular}{|c|c|c|c|}
\hline \multirow{2}{*}{ Product } & \multicolumn{2}{|c|}{ Índex } & \multirow{2}{*}{ Total } \\
\hline & Yes & No & \\
\hline 1 Thesis management & $62 \%$ & $38 \%$ & $100 \%$ \\
\hline 2 Research work management & $58 \%$ & $42 \%$ & $100 \%$ \\
\hline 3 Research days management & $67 \%$ & $33 \%$ & $100 \%$ \\
\hline -Compliance level & \multicolumn{3}{|c|}{ Regular } \\
\hline -Problem level & \multicolumn{3}{|c|}{ Limitation } \\
\hline $\begin{array}{l}4 \text { Management of Articles, } \\
\text { Magazines and Seedbeds }\end{array}$ & $17 \%$ & $83 \%$ & $100 \%$ \\
\hline -Compliance level & \multicolumn{3}{|c|}{ Very little } \\
\hline -Problem level & \multicolumn{3}{|c|}{ Deficiencies } \\
\hline
\end{tabular}


J. Evaluation

The hypothesis of the Pilot Test was accepted because, the change management through the intervention program was positive, since it went from the initial situation of Deficiencies to the final situation of Regular; except for the management of Articles, which remained at the Very little level, probably because the pilot program lasted three months.

\subsection{Discussion}

The results of the pilot test demonstrate the effectiveness of the methodology of technological research as a tool to successfully manage change in an organization.

The methodology was developed taking as an antecedent the administrative process [11].

The proposed methodology systematizes the contribution of seven change management theories [21, 22, 23, 24, 25, 26, 28]; However, its structure is unique. It consists of four stages, ten steps, nine processes, eleven techniques and nine tools.

The theories studied, with the exception of the P-D-V-A model [8; 22], use the administrative route; in the proposed methodology, experimentation and innovation evaluation are also used to minimize the probability of failure.

In the proposed methodology, García's technological research steps, cited by De la Cruz [18], are used, but they also translate into processes, techniques, and tools.

The problem, objectives and theoretical framework are in the diagnostic stage. Unlike Lewin [21], Kübler-Ross [23], Burke and Litwin [8] include the study of the technique and application tools.

The hypothesis, design and innovation test are in the preparation stage. Unlike García, cited by De La Cruz [18] and Shewhart [22], it includes preparatory activities and application tools.

The execution corresponds to the stage of change. Unlike Lewin [21], Shewhart [22], Moss Kanter and Egan [8] and Kotter [28], it includes an information system and application tools.

Other contributions, typical of the proposal, are the Evaluation stage, the consistency graph (Table 7) and all the tools that were used in the pilot test.

The results of the pilot test have allowed to demonstrating the success of the proposed methodology.

Finally, none of the change management models, reviewed in this document, consider the change plan as an invention, but rather as a problem of resistance, which is treated from a behavioral and non-technological point of view.

\section{Conclusions}

Change management has been carried out with administrative models and behavioral strategies without the use of technological tools as a compliment.

For this reason, change in organizations focuses on minimizing resistance to change and not on the change plan.

Change plans within the organization have a low probability of success are not subjected to experimentation.
The change can be new work methods, management, processes, products, markets, suppliers, etc.

This change must be considered as an invention that generates innovation and requires a technological proposal.

The proposal is the methodology of technological research that

It has been designed based on the stages of the administrative process and also on the steps of the technological method.

The proposed methodology is a logical set of stages, steps, processes, techniques, and tools that abstract the technical problem from administrative or social or economic or environmental problems.

The proposed methodology was validated by the pilot test.

The proposed methodology offers a path of a high probability of success because the invention as a process of change is subject to hypothesis testing, before being applied.

The proposed methodology can be applied to any other type of organization.

It is recommended to request the intervention program annually to obtain a more accurate evaluation of the outcome of the change management.

It is also recommended to develop an information system to manage the knowledge of the change.

\section{REFERENCES}

[1] S. Johnson, 2001 ¿Quién se ha llevado mi queso? Ediciones Urano, S.A. (20ª ed.) pág. 106. ISBN 13: 9788479534455.

[2] Á. Fidalgo-Blanco, M. L. Sein-Echaluce, and F. J. García-Peñalvo. 2014 Knowledge spirals in higher education teaching innovation. International Journal of Knowledge Management 10, 4, 16-37. DOI:10.4018/ijkm.2014100102.

[3] Á. Fidalgo-Blanco, M. L. Sein-Echaluce, and F. J. García-Peñalvo. 2015 Epistemological and ontological spirals: From individual experience in educational innovation to the organisational knowledge in the university sector. Program: Electronic library and information systems 49, 3, 266-288. DOI:10.1108/PROG-06-2014-0033.

[4] E. Rubio Royo, S. Cranfield Mckay, J. C. Nelson-Santana, R. N. Delgado Rodríguez, and A. A. Occon-Carreras. 2018. Web Knowledge Turbine as a Proposal for Personal and Professional Self-organisation in Complex Times. Journal of Information Technology Research 11, 1, 70-90. DOI:10.4018/JITR.2018010105

[5] H.A Del Carpio, 2017. Sistema de Indicadores para evaluar la capacidad científica $y$ tecnológica de la UNPRG. Unidad de Investigación, Facultad Ciencias Económicas, Adminstrativas y Contables - FACEAC. Lambayeque, Perú: Universidad Nacional Pedro Ruiz Gallo, pág. 48, Informe Final N 12, Trabajo de Investigación de Desarrollo Tecnológico.

[6] Significados. 2019. significados.com. https://www.significados.com/resistenciaal-cambio/.

[7] J. Sandoval. 2014. Los Procesos de Cambio Organizacional y la Generación de Valor. Estudios Gerenciales, 30, 162-171.

[8] J. McGrath y B. Bates. 2014. El pequeño libro de las grandes teorías del management. Las 89 grandes teorías del management y cómo aplicarlas. Barcelona: Alienta Editorial. ISBN: 978-84-15678-90-8.

[9] L. Reginato, E. Cornacchione y M. Núñez. 2015. Rediseñando la Alta Administracion de la Empresa: Revolución del Equipo y Preparacion para Controles Gerencialese. Suma de Negocios, 6, 13, pág. 123.

[10] A.L. Pérez. 2013. Aplicación del Modelo de Kotter para la Gestión del Cambio en la incorporación de TIC en el proceso de innovación académica con el uso de un BLearning para el C. E. Jahibé. Tesis de Pregrado. Quito, pág. 114.

[11] M.A. Alonso. 2017. Gestión del cambio en las organizaciones - Caso Cargill. Tesis de Masters in Business Administration. Universidad Torcuato Di Tella. Rosario Repositorio Digital UTDT.

[12] P.A. Barreto. 2016. La gestión del cambio para lograr una ventaja competitiva en las empresas. Guayaquil: Universidad Espíritu Santo, Trabajos Finales de Maestría, págs. 1-16. 
[13] R. Soriano-Rivera. 2016. Gestión del cambio: una propuesta metodológica desde el proceso estratégico. Revista de Ciencias de la Gestión, 1, 1, 38-86. ISSN: 10199403.

[14] P.M. Ortega y C.G. Solano. 2015. La gestión del cambio organizacional en entidades públicas del Poder Ejecutivo Peruano: Una aplicación de la teorías de cambio provenientes de la gestión privada. Tesis para obtener el título profesional de Licenciado en Gestión. Facultad de Gestión y Alta Dirtección, Pontificia Universidad Católica del Perú. Lima: TESIS PUCP.

[15] H.A. Del Carpio, P.A. Del Carpio y F.J. García-Peñalvo. 2018. A system of indicators for assesing scientific and technological capacity at local universities. En Actas de Sixth International Conference on Technological Ecosystems for Enhancing Multiculturality. ACM Press, New York, NY, 221-227. doi $10.1145 / 3284179.3284219$.

[16] J. Cegarra. 2004. Metodología de la investigación científica y tecnológica. Madrid: Ediciones Díaz de Santos.

[17] E. Anduiza, I. Crespo y M. Méndez. 2009. Metodología de la ciencia política. CIS Centro de Investigaciones Sociológicas. Cuadernos Metodológicos. Madrid.

[18] C. De La Cruz. 2016. Metodología de la investigación tecnológica en ingeniería. Ingenium, 1. Universidad Continental, Lima.

[19] M. Ruiza y otros. 2004. Kur Lewin. España: Biografás y Vidas. La Enciclopedia Biográfica en línea.

[20] G. Novelo. 2018. Biografias. Kurt Lewin: Su vida y su obra en pocas palabras. México, D.F.: Psicología al día.

[21] Infoamérica. 2019. Kurt Lewin (1980-1947). Observatorio de la libertad de Prensa en América Latina - UNESCO.

[22] W.D. Guillen. 2017. Implementacion de un modelo de mejora en el ciclo PHVA el el proceso de suministros para incrementar la puntualidad en la entrega de materiales de una empresa siderúrgica de Áncash en Perú. Trujillo: UPN.

[23] D. Cuadrado 2010. Las cinco etapas del cambio. Capital Humano, 241, 54-59.

[24] R. Ordoñez. 2010. Cambio, creatividad e innovación. Buenos Aires: Ediciones Granica S.A. págs. 66-83. 978-950-641-571-6.

[25] R. $2009 . \quad$ Moss-Kanter. rosabethmosskanter.blogspot http://rosabethmosskanter.blogspot.com/2009/02/biografia.html.
[26] T. Drobny. 2013. Estudio de cambio organizacional a partir de la experiencia de instalación de un hospital público. Tesis para optar el Título de Psicología. Carrera de Psicología, Facultad de Ciencias Sociales. Santiago de Chile: Universidad de Chile.

[27] F. Guardia. 2016. Biografia de john kotter. Eldesafiodelcambioorganizacional.

[28] J.P. Kotter. 2011. Liderar el cambio. Por qué fracasan los intentos de transformación. Harvard Business Review, págs. 78-85.

[29] H.A. Del Carpio and F.J. García-Peñalvo. 2015. Design of the instrument to evaluate innovation in healthcare centers. In Proceedings of the Third International Conference on Technological Ecosystems for Enhancing Multiculturality (TEEM'15) (Porto, Portugal, October 7-9, 2015), G.R. Alves and M.C. Felgueiras Eds. ACM, New York, NY, 481-487. DOI= http://dx.doi.org/10.1145/2808580.2808652.

[30] UTP. 2012. Manual de Organización y Funciones de la Unidad de Investigación (Pregrado FIIS). Facultad de Ingeniería Industrial y de Sistemas, Universidad Tecnológica del Perú. Lima, pág. 16, Documento de Gestión Institucional.

[31] PUCP. 2019. Dirección de Gestión de la Investigación. Recuperado el 30 de enero de 2019. https://www.pucp.edu.pe/unidad/direccion-gestion-investigacion/.

[32] INS. 2011. Modelo de Organización y Funciones de la Oficina / Unidad Regional de Investigación en Salud. Instituto Nacional de Salud, Ministerio de Salud. Lima, pág. 60, Documento de Gestión Institucional.

[33] PUJ. 2019. La Oficina de Investigación, Desarrollo e Innovación. Recuperado el 30 de enero de 2019. https://www.javerianacali.edu.co/node/ 11610.

[34] USAL. 2019. Vicerrectorado de Investigación y Transferencia. Recuperado el 30 de enero de 2019. https://www.usal.es/vicerrectorado-de-investigacion-ytransferencia.

[35] MINEDU. 2014. Leu Universitaria. Ley $N^{\circ}$ 30220. Lima : Ministerio de Educación.

[36] L.E. Becerra, R. Zárate and D.A. Rodríguez. 2015. Gestión de la gestión universitaria: Un escenario académico para la apropiación del conocimiento. Revista Internacional de Tecnología, Ciencia y Sociedad. IV, 2, 215-226. ISSN 25304895.

[37] R. Abello and K. Pardo. 2014. Modelos de investigación y desarrollo en instituciones de educación superior en Colombia: El caso de la Universidad del Norte en la región Caribe de Colombia. Investigación \& Desarrollo, XXII, 2, 187211. ISSN 2011-7574. 